\title{
SOURCES AND REGULATION OF NITRIC OXIDE SYNTHESIS IN UTERUS SMOOTH MUSCLE CELLS
}

\author{
H. V. DANYLOVYCH, Yu. V. DANYLOVYCH, T. V. BOHACH, \\ V. T. HURSKA, S. O. KOSTERIN \\ Palladin Institute of Biochemistry, National Academy \\ of Sciences of Ukraine, Kyiv; \\ e-mail: danylovych@biochem.kiev.ua
}

Received: 28 February 2019; Accepted: 17 May 2019

\begin{abstract}
It was proved that NO synthesis in isolated mitochondria of rat uterus smooth muscle depended on the entry of exogenous $\mathrm{Ca}^{2+}$ to mitochondria (inhibited by 1-10 $\mathrm{mM} \mathrm{Mg}^{2+}$ in the absence of ATP and by $10 \mu \mathrm{M}$ ruthenium red) and was suppressed by calmodulin antagonists (0.1-10 $\mu \mathrm{M}$ calmidazolium and 1-100 $\mu \mathrm{M}$ trifluoperazine). It was blocked by $N^{G}$-nitro-L-arginine, a known antagonist of the constitutive NO-synthase, with a half-maximal inhibition effect at about $25 \mu \mathrm{M}$. Moderate deholesterinization of the plasma membrane of myocytes after processing with $0.01 \%$ digitonin was followed by increased nitric oxide biosynthesis by cells. The data obtained suggested that mitochondria and plasmalemma is a possible source of NO synthesis in uterine myocytes.
\end{abstract}

Ke y w o rd s: nitric oxide, mtNOS, mitochondria, calcium, uterus smooth muscle.

$\mathrm{N}$ itric oxide (NO) is a universal signaling and regulatory molecule in cells. One of the important nitric oxide biological actions is control of smooth muscle contractile function that is involved in the maintenance of normal functioning of internal organs, in particular, the genitourinary system $[1,2]$. Both NO production and sensitivity to the molecule decrease at the end of pregnancy and precede the onset of labor [3]. Nitric oxide donors cause relaxation of myometrium in non-pregnant women as well as those at different stages of pregnancy. A corresponding decrease in the contractile activity of uterine smooth muscle cells is also shown in certain animal species, including rats and primates, at different periods of the functional organ activity $[4,5]$. The ability of NO to relax myometrium generated an interest in its formation in uterus myocytes. However, subcellular sources of nitric oxide in myometrium remain unknown. An important source of NO in uterus smooth muscle cells, given other tissues, may be mitochondria. Mitochondria play an important role in the processes of $\mathrm{Ca}^{2+}$-signaling and $\mathrm{Ca}^{2+}$-dependent control of smooth muscle contraction [6]. Over the past twenty years, it has been found that NO regulates energy, metabolic and transport processes in mitochondria [7]. The results of recent studies have indicated that NO is an important link in maintaining an optimal concentration of Ca ions in the myoplasm as well as in the mitochondrial matrix $[2,8,9]$.

To date, the mitochondrial localization of NOsynthase (NOS) has been shown for some organs and tissues of mammals: liver [10], heart [8], brain [11], skeletal muscle (diaphragm) [12], kidneys [13], thymus [14]. Our previous studies demonstrated NO formation in mitochondria of uterine smooth muscle cells using laser confocal microscopy and specific fluorescence probes. The conditions for determination of NO-synthase activity (mtNOS) in isolated rat myometrium mitochondria with the use of DAF-FM fluorescence probe and flow cytometry method were established. The optimal work of mtNOS in isolated myometrium mitochondria requires the presence of $\mathrm{Ca}^{2+}$, NADPH and L-arginine in the incubation medium. The key kinetic parameters of this enzymatic reaction were previously calculated, and it was

(C) 2019 Danylovych H. V. et al. This is an open-access article distributed under the terms of the Creative Commons Attribution License, which permits unrestricted use, distribution, and reproduction in any medium, provided the original author and source are credited. 
shown that the biosynthesis of nitric oxide by mitochondria depends greatly on their energy level [15].

Experimental data on other objects indicated that mtNOS is constitutively expressed in mitochondria, is bound to the internal mitochondrial membrane, and its biochemical properties are similar to those of constitutive NOS, in particular, a neuronal isoform [16]. Therefore, predictably, its activity is determined by the intensity of exogenous $\mathrm{Ca}^{2+}$ flow to the matrix and significantly depends on the effectiveness of the $\mathrm{Ca}^{2+}$-calmodulin complex formation, which is the main cofactor of the constitutive isoforms. There is no relevant information available regarding the smooth muscle and, in particular, the uterus. In smooth muscle cells, both the plasma membrane caveolae, where endothelial NOS (eNOS) is located, and the sarcoplasmic reticulum can also serve as important sources of nitric oxide synthesis.

Thus, the present work aimed to prove that NO synthesis in myometrium mitochondria has $\mathrm{Ca}^{2+}$ calmodulin-dependent character using the constitutive NOS inhibitor, $\mathrm{Ca}^{2+}$ blockers in mitochondria and calmodulin antagonists. It was also important to find out the possible contribution of non-mitochondrial NO sources to its production by myocytes in the uterus.

\section{Materials and Methods}

Experiments were carried out on wild white rats (females) weighing 150-170 g. All the requirements for working with laboratory animals were followed "Bioethical expertise of preclinical and other scientific researches conducted on animals" (Kyiv, 2006) and "European Convention for the Protection of Vertebrate Animals Used for Experimental and Scientific Purposes" (Strasbourg, 1986). The animals were decapitated after inhalation anesthesia with chloroform.

The fraction of isolated mitochondria was obtained from the myometrium of non-pregnant rats using a standard approach with differentiation centrifugation [17]. The protein content of the fraction was determined by the Bradford assay [18].

The composition of $2 \mathrm{ml}$ working medium for the determination of NO-synthase activity in isolated mitochondria (mM): 20 Hepes ( $\left.\mathrm{pH} 7.4,24^{\circ} \mathrm{C}\right)$, $2 \mathrm{~K}^{+}$-phosphate buffer $\left(\mathrm{pH} 7.4,24^{\circ} \mathrm{C}\right), 120 \mathrm{KCl}, 5$ pyruvate, 5 succinate, $0.05 \mathrm{~L}$-arginine, $0.1 \mathrm{Ca}^{2+}$, $0.01 \mathrm{NADPH}, 0.01$ tetrahydrobiopterin. The protein content of the mitochondrial fraction in the reaction medium was 15-20 $\mu \mathrm{g}$ [15]. The incubation time was
$30 \mathrm{~min}$ at $24^{\circ} \mathrm{C}$. In some experiments, there was no $\mathrm{Ca}^{2+}$ in the medium (nominally non-calcium medium).

The active acid membrane-permeable form of NO-specific fluorescent dye DAF-FM (diaminofluorescein-FM) was used. DAF-FM was introduced into the working medium at a final experimentally-selected concentration of $0.5 \mu \mathrm{M}$. Measurements were performed using a flow cytometer COULTER EPICS $\mathrm{XL}^{\mathrm{TM}}$ (Beckman Coulter, USA) with an argon laser $\left(\lambda_{\mathrm{ex}}=488 \mathrm{~nm}, \lambda_{\mathrm{fl}}=515 \mathrm{~nm}\right.$ (channel Fl1).

Myocytes were isolated from rat uterus using collagenase and soybean trypsin inhibitor by the Mollard method [19]. The procedures of cell immobilization for confocal scanning, washing the nonattached myocytes away and all experimental research were carried out in the physiological Hanks' solution (mM): $136.9 \mathrm{NaCl}, 5.36 \mathrm{KCl}, 0.44 \mathrm{KH}_{2} \mathrm{PO}_{4}$, $0.26 \mathrm{NaHCO}_{3}, 0.26 \mathrm{Na}_{2} \mathrm{HPO}_{4}, 0.03 \mathrm{CaCl}_{2}, 10$ Hepes $\left(\mathrm{pH}, 7.4,24{ }^{\circ} \mathrm{C}\right), 0.1 \%$ glucose. The spatial distribution of fluorescent dyes in the cell was investigated on a laser scanning confocal microscope LSM 510 META (Carl Zeiss, Germany) using immobilized on poly-L-lysine myocytes. Cell nuclei were visualized by fluorescent dye Hoechst 33342 at a concentration of $50 \mu \mathrm{M}$. Immobilized myocytes were loaded with NO-sensitive fluorescence probe DAF-FM at a concentration of $10 \mu \mathrm{M}$ for $15 \mathrm{~min}$ at $24^{\circ} \mathrm{C}$.

The experiments with the confocal microscope were conducted in Multi-Track mode. Hoechst 33342 fluorescence was excited by the $405 \mathrm{~nm}$ laser line, and BP 420-480 optical filter was used to register the signal. The excitation of the DAF-FM fluorescence was conducted at a wavelength of $488 \mathrm{~nm}$, and its registration was in the range of 505-530 nm (BP 505530 optical filter). The study of the fluorescent dye distribution kinetics in the cell was performed in the Time Series mode, and for the quantitative analysis, the ROI (Region of Interest) function was used that allows obtaining a time dependence of the fluorescence intensity averaged over the selected region.

The statistical analysis of the obtained data was carried out using standard programs with Student's $t$-test.

\section{Results and Discussion}

In the presence of exogenous $50 \mu \mathrm{M} \mathrm{L}$-arginine and $100 \mu \mathrm{M} \mathrm{Ca}^{2+}$, which optimal concentrations for NO synthesis by isolated mitochondria were previously experimentally selected [15], and with the availability of $10 \mu \mathrm{M}$ NADPH, $10 \mu \mathrm{M}$ tetrahydrobio- 
pterin and the respiratory substrates in the incubation medium, mtNOS activity was $0.28 \pm 0.04$ DAFFM fluorescence relative units per $\mathrm{mg}$ of protein per $\min (n=5)$. This value corresponds to the results obtained in the previous work on this model.

To demonstrate the role of exogenous Ca ions in NO biosynthesis by mitochondria, we applied $\mathrm{Mg}^{2+}$, which was added directly to the incubation medium. $\mathrm{Mg}^{2+}$ is a cofactor of enzymes that are required for ATP functional activity. $\mathrm{Mg}^{2+}$ affect the $\mathrm{Ca}^{2+}$ affinity to specific $\mathrm{Ca}^{2+}$-binding proteins, in particular, calmodulin, by modulating the intracellular $\mathrm{Ca}^{2+}$-signal. In general, $\mathrm{Mg}^{2+}$ is considered as the major intracellular antagonist of $\mathrm{Ca}^{2+}$ [20]. In mitochondria, $\mathrm{Mg}^{2+}$ inhibits the permeability transition pore, $\mathrm{Ca}^{2+}$-uniporter (MCU), mitochondrial ryanodine receptor (mRyR), $\mathrm{Na}^{+} / \mathrm{Ca}^{2+}$-exchanger (in cardiomyocytes), and $\mathrm{H}^{+} / \mathrm{Ca}^{2+}$-exchanger (in myometrium) [20-22].

In the absence of $\mathrm{Ca}^{2+}$ in the reaction medium, the effect of $\mathrm{Mg}^{2+}$ on NO production was not significant. Only in the presence of exogenous $\mathrm{Ca}^{2+}$, there was an inhibition of nitric oxide biosynthesis by mitochondria, which is dependent on $\mathrm{Mg}^{2+}$ concentration (Fig. 1, A).

The inhibiting effect may account for whether the ability of high $\mathrm{Mg}^{2+}$ concentration to block $\mathrm{Ca}^{2+}$ accumulation in mitochondria or a decrease in $\mathrm{Ca}^{2+}$

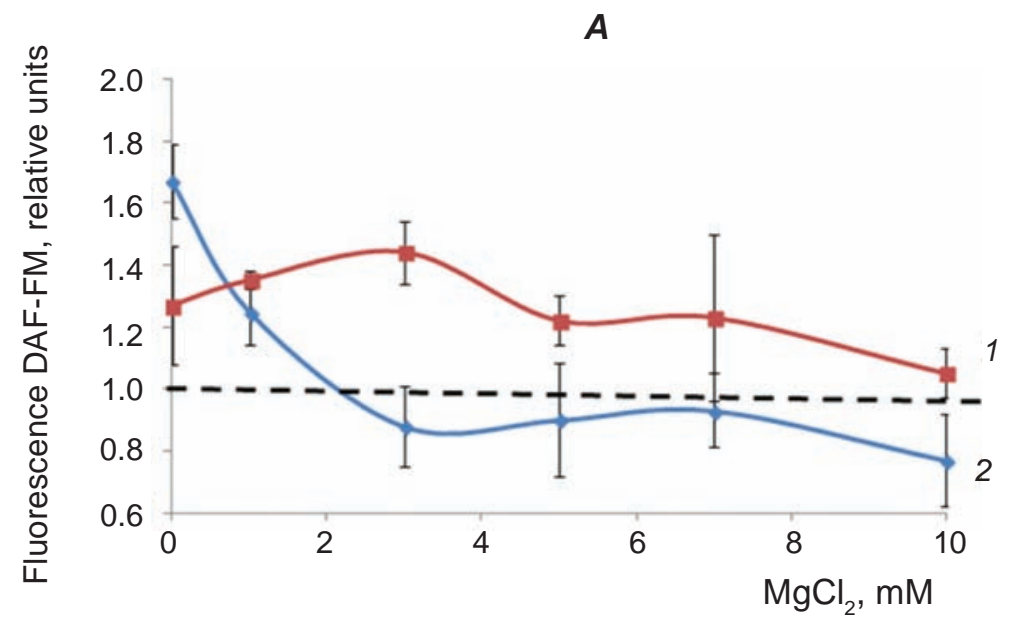

B

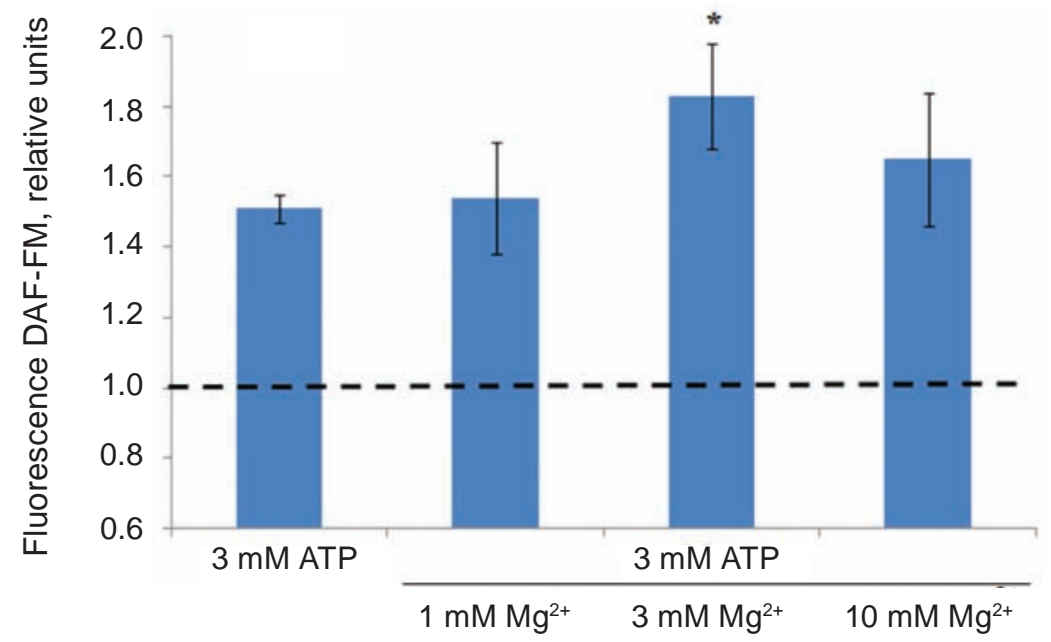

Fig. 1. Influence of $\mathrm{Mg}$ ions on nitric oxide synthesis in isolated mitochondria of the myometrium. $\boldsymbol{A}-1-$ in

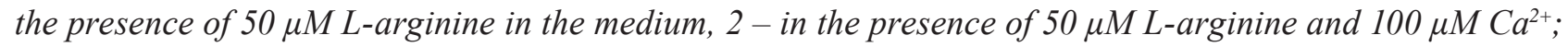
$\boldsymbol{B}$ - in the medium with $50 \mu M$ L-arginine and $100 \mu M \mathrm{Ca}^{2+}$ as well as $3 \mathrm{mM} \mathrm{ATP}(M \pm m, n=5)$. The endogenous (in the absence of L-arginine and $\mathrm{Ca}^{2+}$ in the medium) synthesis of NO in mitochondria is taken as " 1 "; * changes are significant $(P \leq 0.05)$ relative to the effect of $3 \mathrm{mM}$ ATP. Flow cytometry data 
affinity to calmodulin, since the $\mathrm{Ca}^{2+}$-calmodulin complex itself regulates electronic transport in constitutive NOS [23].

Addition of $3 \mathrm{mM}$ ATP to the mitochondria affected the NO production only slightly (Fig. 1, B). It was shown earlier that $\mathrm{Ca}^{2+}$ accumulation by mitochondria in the suspension of permeabilized uterine myocytes increases significantly in the presence of ATP together with $\mathrm{Mg}^{2+}$ in the medium $\left(\mathrm{Mg}^{-\mathrm{ATP}^{2-}}\right.$ complex) [24]. In our studies, only optimal equimolar concentrations of ATP and $\mathrm{Mg}^{2+}(3 \mathrm{mM})$ additionally stimulated NO synthesis provided that the exogenous $100 \mu \mathrm{M} \mathrm{Ca}^{2+}$ is present. Lower $(1 \mathrm{mM})$ or high $(10 \mathrm{mM})$ concentrations of $\mathrm{Mg}^{2+}$ did not have a reliable stimulatory effect on NO synthesis (Fig. 1, B).

The use of $25 \mu \mathrm{M} \mathrm{N}{ }^{G}$-nitro-L-arginine, a known inhibitor of constitutive NOS, resulted in significant inhibition (about $50 \%$ ) of NO biosynthesis in mitochondria. Ruthenium red $(10 \mu \mathrm{M})$, an inhibitor of $\mathrm{Ca}^{2+}$ transport in the internal membrane of mitochondria, in particular $\mathrm{Ca}^{2+}$-uniporter, also inhibited the synthesis of NO in mitochondria (Fig. 2).

Thus, NO synthesis by rat myometrium mitochondria in some biochemical properties is similar to that carried out by the constitutive $\mathrm{Ca}^{2+}$-dependent NOS. Although NO synthesis is observed in the absence of exogenous $\mathrm{Ca}^{2+}$, since the $\mathrm{Ca}^{2+}$ concentration in the matrix is sufficient for enzymatic activity, the flow of $\mathrm{Ca}^{2+}$ to mitochondria significantly stimulates NO production.

The dependence of the enzymatic activity on $\mathrm{Ca}^{2+}$ is the only fundamental difference between the constitutive and the inducible isoforms of NOS that accounts for the formation of $\mathrm{Ca}^{2+}$-calmodulin complex. The binding site of calmodulin is located between the reductase and the oxygenase domains of NOS, being a sequence of 20-25 amino acids. Calmodulin binding regulates the electron transport from the reductase to the oxygenase domain, as well as in the reductase domain [23]. nNOS (neuronal NOS) and eNOS contain 40-50 amino acids in the FMN subdomain, which form an autoinhibitory loop that blocks the interaction with calmodulin at low $\mathrm{Ca}^{2+}$ concentrations and inhibits the transport of electrons from FMN to heme in the absence of $\mathrm{Ca}^{2+}-$ calmodulin [25].

It should be noted that ruthenium red inhibits the binding of $\mathrm{Ca}^{2+}$ to calmodulin [26]. It was shown on the fraction of isolated myometrium mitochondria that calmodulin antagonists $(10 \mu \mathrm{M}$ calmidazolium and $100 \mu \mathrm{M}$ of trifluoperazine) completely

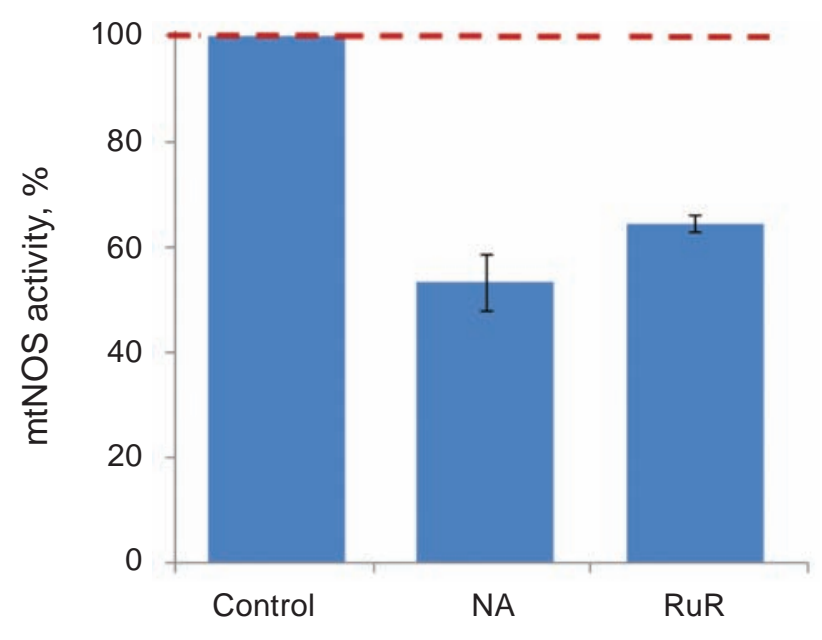

Fig. 2. The activity of mtNOS in the presence of $N^{G_{-}}$ nitro-L-arginine $(25 \mu \mathrm{MNA})$, an inhibitor of $\mathrm{Ca}^{2+}$ dependent NO-synthase, and ruthenium red $(10 \mu \mathrm{M}$ $\mathrm{RuR})$, an inhibitor of $\mathrm{Ca}^{2+}$ transport in mitochondria $(M \pm m, n=5)$. Flow cytometry data

inhibit the energy-dependent $\mathrm{Ca}^{2+}$ accumulation by organelles and cause the depolarization of mitochondrial membrane [27]. These results suggest that $\mathrm{Ca}^{2+}$-dependent NO biosynthesis by energized mitochondria is sensitive to these compounds. In our studies, calmodulin antagonists, namely calmidazolium $(0.1-10 \mu \mathrm{M})$ and trifluoperazine $(1-100 \mu \mathrm{M})$, led to a concentration-dependent inhibition of NO biosynthesis in mitochondria at $100 \mu \mathrm{M} \mathrm{Ca}^{2+}$ in an incubation medium (Fig. 3). The inhibition of NO synthesis in myometrium mitochondria by calmodulin antagonists suggests that there is a functionally active constitutive isoform of NOS, whose work is regulated by the $\mathrm{Ca}^{2+}$-calmodulin complex. The inhibitory effect of calmodulin antagonists can be related to three mechanisms: direct suppression of calmodulin-dependent enzyme activation, blockage of $\mathrm{Ca}^{2+}$ transport in mitochondria or their de-energization.

The application of the modern fluorescent probe DAF-FM enables to detect directly, quickly and reliably NO products at low nitric oxide concentrations (2-5 nM) in intact cells, and the method of laser confocal microscopy provides the visualization of its formation and, using specific enzyme inhibitors and chemical modifiers of subcellular membrane structures, allows to prove NO biosynthesis connection with certain cell compartments [28]. The biosynthesis of NO in the myocytes may be related not only to mitochondria: constitutive NOS are associated with 

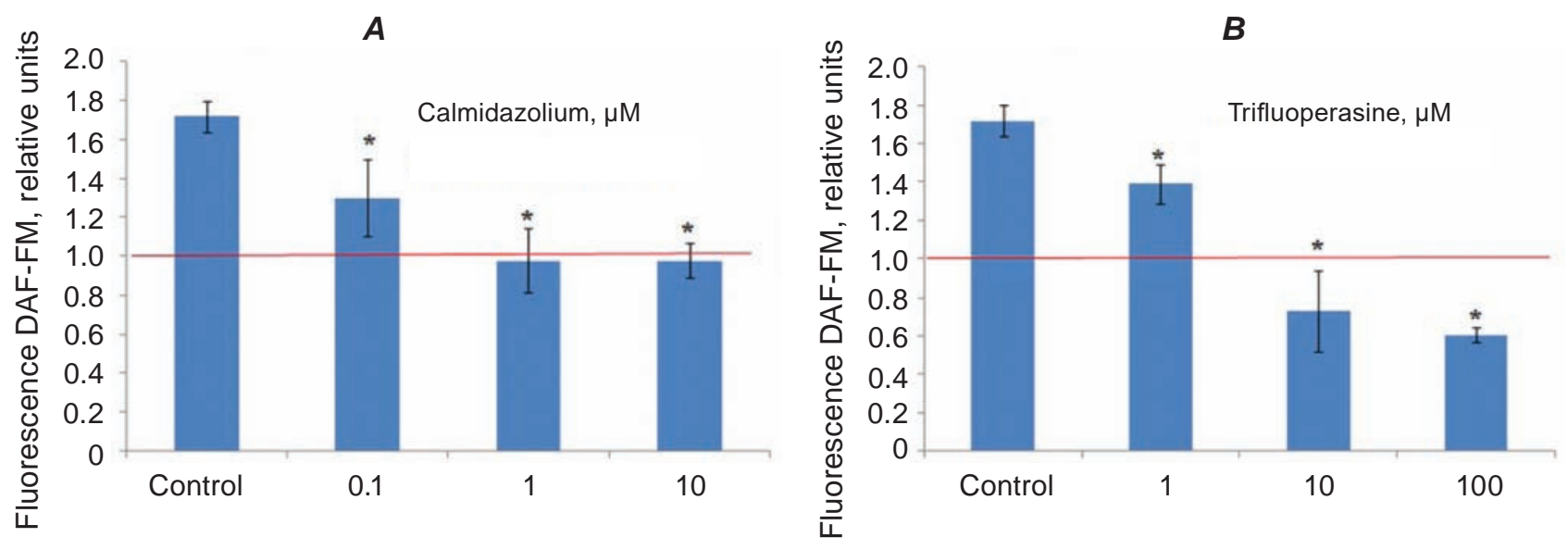

Fig. 3. Biosynthesis of nitric oxide by isolated mitochondria in the presence of calmodulin antagonists. ${ }^{*} P<0.05$ relative to control $(M \pm m, n=5)$. Flow cytometry data

the plasma membrane, sarcoplasmic reticulum and other intracellular structures [7].

Thapsigargin, a high-affinity SERCA-pump inhibitor, at nanomolar concentration causes the depletion of $\mathrm{Ca}^{2+}$ store in sarcoplasmic reticulum [29], which can suppress $\mathrm{Ca}^{2+}$-dependent $\mathrm{NO}$ biosynthesis in this compartment. In our researches, the treatment of intact myocytes with $1 \mu \mathrm{M}$ thapsigargin did not lead to significant changes in DAF-FM fluorescence. Only an increase of thapsigargin concentration up to 2-3 $\mu \mathrm{M}$ resulted in a decrease in NO-sensitive DAFFM fluorescence (Fig. 4, A). It might be assumed that NO synthase associated with sarcoplasmic reticulum is involved in nitric oxide synthesis in uterine myocytes.

The treatment of myocytes with digitonin $(0.01 \%)$, that do not affect the functioning of intracellular $\mathrm{Ca}^{2+}$ transport systems, but cause an increase in nonspecific permeability of the plasma membrane [30], led to an increase in NO production by cells and a corresponding increase in DAF-FM fluorescence (Fig. 4, B).

Digitonin interacts with plasma membrane cholesterol, forming micelles and vesicles, which disrupts the lipid bilayer and makes the membrane more permeable to ions and substrates [31]. The latter leads to the destruction of caveolae and the possible eNOS dissociation from caveolin - a powerful enzyme inhibitor [32]. These events are an explanation for the increased NO synthesis by myocytes and evidence that the plasma membrane, along with mitochondria, is an important source of nitric oxide synthesis in myometrium cells.

Application of $1 \mathrm{mM}$ methyl- $\beta$-cyclodextrin $(\mathrm{M} \beta \mathrm{CD})$, a cyclic oligosaccharide that forms cho- lesterol complexes and is used as a pharmacological agent for cholesterol removal from membranes [33], and digitonin in ultrahigh concentrations $(0.1 \%)$, which disrupt subcellular intact structures [30], led to DAF-FM fluorescence signal reduction within $50 \%$ relative to the control level (Fig. 5).

It is well known that the plasma membrane is the most enriched with cholesterol, while the internal mitochondrial membrane and the endoplasmic reticulum membrane also contain a certain amount of it. Perhaps, a "hard" deholesterination of subcellular membranes results in their significant destruction and, hence, the inhibition of the activity of membrane-associated enzymes, in particular, NOS.

Thus, the biosynthesis of nitric oxide by myometrium mitochondria largely depends on the presence of exogenous $\mathrm{Ca}^{2+}$ and is suppressed by calmodulin antagonists, and, according to these properties, corresponds to the functioning of $\mathrm{Ca}^{2+}$ calmodulin-dependent isoforms of NOS. The latter is proven by $\mathrm{N}^{\mathrm{G}}$-nitro-L-arginine inhibitory effect on the enzyme. The plasma membrane of uterine myocytes may also be a source of nitric oxide generation.

The authors are grateful to doctor S. O. Karahim from the Department of Muscle Biochemistry, Palladin Institute of Biochemistry for the assistance in the confocal scanning and processing of confocal microscopy data.

Conflict of interest. Authors have completed the Unified Conflicts of Interest form at http:// ukrbiochemjournal.org/wp-content/uploads/2018/12/ coi_disclosure.pdf and declare no conflict of interest. 
A
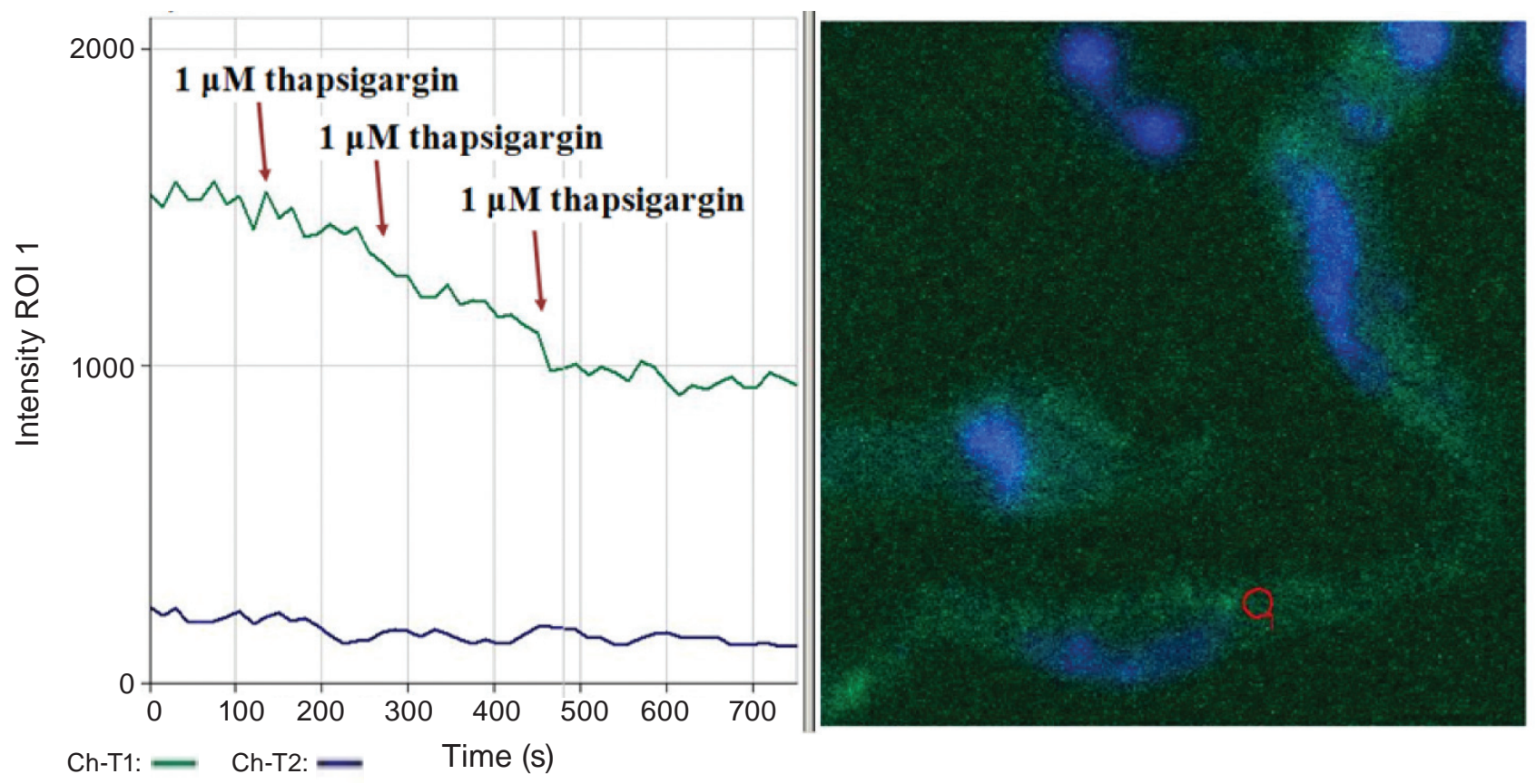

B
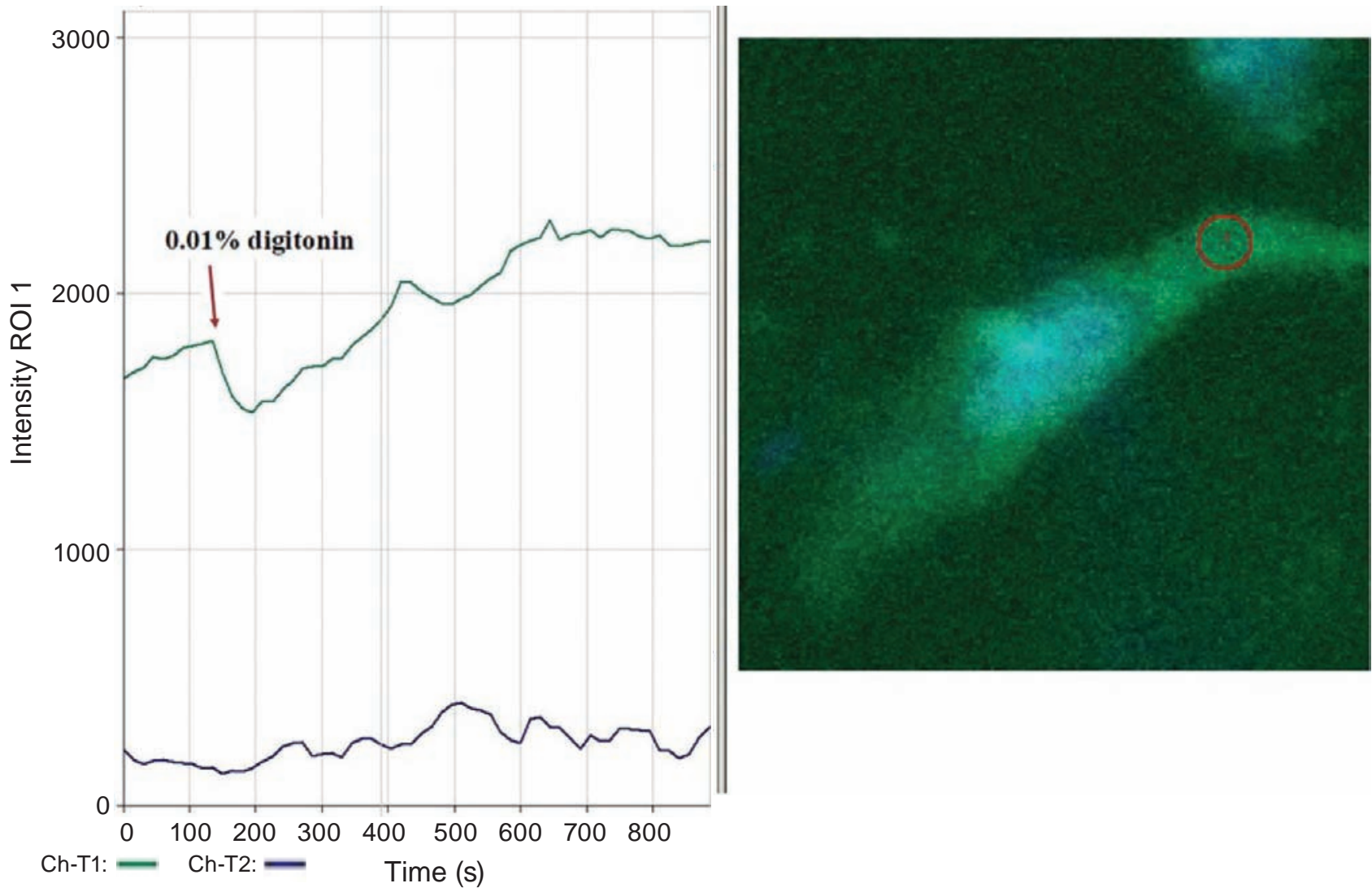

Fig. 4. Influence of 1-3 $\mu M$ thapsigargin (A) and 0.01\% digitonin (B) on nitric oxide production in uterine myocytes. Laser confocal microscopy data. For the quantitative analysis of the results, the ROI (region of interests) function was used. $10 \mu M$ DAF-FM (NO), green curve, channel 1; $50 \mu M$ Hoechst 33342 (nucleus), blue curve, channel 2 


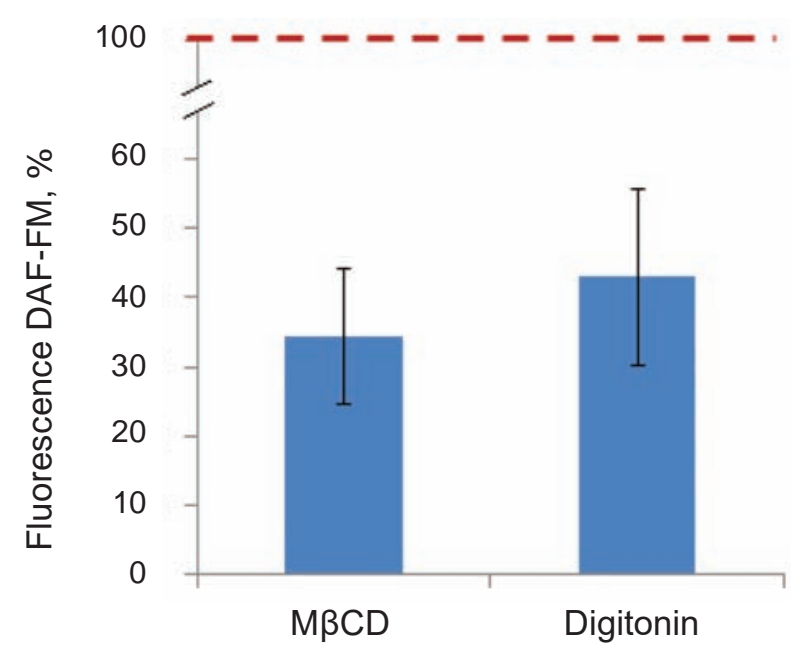

Fig. 5. Effects of high detergent concentrations (1 $\mathrm{mMM} M C D$ and $0.1 \%$ digitonin) on nitric oxide biosynthesis in myometrium cells; NO synthesis in the absence of detergents is taken as 100\%. Laser confocal microscopy data. For the quantitative analysis, 5-6 cells from different independent experiments were used, $(M \pm m)$

\section{ДЖЕРЕЛА I ЗАКОНОМІРНОСТI СИНТЕЗУ ОКСИДУ АЗОТУ В КЛІТИНАХ ГЛАДЕНЬКОГО М'ЯЗА МАТКИ}

Г. В. Данилович, Ю. В. Данилович,

Т. В. Богач, В. Т. Гурська, С. О. Костерін

Інститут біохімії ім. О. В. Палладіна НАН України, Київ;

e-mail: danylovych@biochem.kiev.ua

Доведено, що синтез NO в ізольованих мітохондріях гладенького м'яза матки щурів є залежним від надходження екзогенного $\mathrm{Ca}^{2+}$ до мітохондрій (інгібується 1-10 мМ Mg${ }^{2+}$ за відсутності АТР, 10 мкМ рутенієвим червоним), пригнічується антагоністами кальмодуліну (0,1-10 мкМ кальмідозоліумом та 1-100 мкМ трифлуоперазином). Він блокується відомим антагоністом конститутивних $\mathrm{NO}$-синтаз $\mathrm{N}^{\mathrm{G}}$-нітро-L-аргініном 3 ефектом полумаксимального інгібування близько 25 мкМ. Помірна дехолестеринізація плазматичної мембрани міоцитів за їх обробки $0,01 \%$ им дигітоніном приводить до зростання синтезу NO клітинами, що свідчить на користь того, що плазмалема є можливим джерелом NO в міоцитах матки.
Кл ючов і слов а: оксид азоту, mtNOS, мітохондрії, кальцій, гладенький м'яз матки.

\section{References}

1. Ahmad A, Dempsey SK, Daneva Z, Azam M4, Li N, Li PL6, Ritter JK. Role of nitric oxide in the cardiovascular and renal systems. Int $\mathrm{J} \mathrm{Mol}$ Sci. 2018; 19(9). pii: E2605.

2. Zheng J, Zhai K, Chen Y, Zhang X, Miao L, Wei B, Ji G. Nitric oxide mediates stretchinduced $\mathrm{Ca}^{2+}$ oscillation in smooth muscle. $J$ Cell Sci. 2016; 129(12): 2430-2437.

3. Buxton IL. Regulation of uterine function: a biochemical conundrum in the regulation of smooth muscle relaxation. Mol Pharmacol. 2004; 65(5): 1051-1059.

4. Sladek SM, Magness RR, Conrad KP. Nitric oxide and pregnancy. Am J Physiol. 1997; 272(2 Pt 2): R441-R463.

5. Wetzka B, Schäfer WR, Stehmans A, Zahradnik HP. Effects of nitric oxide donors on the contractility and prostaglandin synthesis of myometrial strips from pregnant and nonpregnant women. Gynecol Endocrinol. 2001; 15(1): 34-42.

6. Yamamura H, Kawasaki K, Inagaki S, Suzuki Y, Imaizumi Y. Local $\mathrm{Ca}^{2+}$ coupling between mitochondria and sarcoplasmic reticulum following depolarization in guinea pig urinary bladder smooth muscle cells. Am J Physiol Cell Physiol. 2018; 314(1): C88-C98.

7. Zaobornyj T, Ghafourifar P. Strategic localization of heart mitochondrial NOS: a review of the evidence. Am J Physiol Heart Circ Physiol. 2012; 303(11): H1283-H1293.

8. Dedkova EN, Blatter LA. Measuring mitochondrial function in intact cardiac myocytes. J Mol Cell Cardiol. 2012; 52(1): 4861.

9. Drumm BT, Rembetski BE, Cobine CA, Baker SA, Sergeant GP, Hollywood MA, Thornbury KD, Sanders KM. $\mathrm{Ca}^{2+}$ signalling in mouse urethral smooth muscle in situ: role of $\mathrm{Ca}^{2+}$ stores and $\mathrm{Ca}^{2+}$ influx mechanisms. J Physiol. 2018; 596(8): 1433-1466.

10. Tatoyan A, Giulivi C. Purification and characterization of a nitric-oxide synthase from rat liver mitochondria. J Biol Chem. 1998; 273(18): 11044-1048. 
11. Lores-Arnaiz S, D'Amico G, Czerniczyniec A, Bustamante J, Boveris A. Brain mitochondrial nitric oxide synthase: in vitro and in vivo inhibition by chlorpromazine. Arch Biochem Biophys. 2004; 430(2): 170-177.

12. Alvarez S, Boveris A. Mitochondrial nitric oxide metabolism in rat muscle during endotoxemia. Free Radic Biol Med. 2004; 37(9): 1472-1478.

13. Boveris A, Valdez LB, Alvarez S, Zaobornyj T, Boveris AD, Navarro A. Kidney mitochondrial nitric oxide synthase. Antioxid Redox Signal. 2003; 5(3): 265-271.

14. Bustamante J, Bersier G, Romero M, Badin RA, Boveris A. Nitric oxide production and mitochondrial dysfunction during rat thymocyte apoptosis. Arch Biochem Biophys. 2000; 376(2): 239-247.

15. Danylovych HV, Danylovych YV, Gulina MO, Bohach TV, Kosterin SO. NO-synthase activity in mitochondria of uterus smooth muscle: identification and biochemical properties. Gen Physiol Biophys. 2019; 38(1): 39-50.

16. Carreras MC, Poderoso JJ. Mitochondrial nitric oxide in the signaling of cell integrated responses. Am J Physiol Cell Physiol. 2007; 292(5): C1569-C1580.

17. Kolomiets OV, Danylovych IuV, Danylovych HV, Kosterin SO. $\mathrm{Ca}^{2+}$ accumulation study in isolated smooth muscle mitochondria using fluo-4 AM. Ukr Biokhim Zhurn. 2013; 85(4): 30-39. (In Ukrainian).

18. Bradford MM. A rapid and sensitive method for the quantitation of microgram quantities of protein utilizing the principle of protein-dye binding. Anal Biochem. 1976; 72: 248-254.

19. Mollard P, Mironneau J, Amedee T, Mironneau C. Electrophysiological characterization of single pregnant rat myometrial cells in short-term primary culture. Am J Physiol. 1986; 250(1 Pt 1): C47-C54.

20. Pilchova I, Klacanova K, Tatarkova Z, Kaplan P, Racay P. The Involvement of $\mathrm{Mg}^{2+}$ in Regulation of Cellular and Mitochondrial Functions. Oxid Med Cell Longev. 2017; 2017: 6797460.

21. Boelens AD, Pradhan RK, Blomeyer CA, Camara AK, Dash RK, Stowe DF. Extra-matrix $\mathrm{Mg}^{2+}$ limits $\mathrm{Ca}^{2+}$ uptake and modulates $\mathrm{Ca}^{2+}$ uptake-independent respiration and redox state in cardiac isolated mitochondria. $J$ Bioenerg Biomembr. 2013; 45(3): 203-218.
22. Kolomiets OV, Danylovych YuV., Danylovych GV. $\mathrm{H}^{+}-\mathrm{Ca}^{2+}$ Exchanger in the Myometrium Mitochondria: Modulation by Exogenous and Endogenous Compounds. Int $J$ Physiol Pathophys. 2015; 6(4): 287-297.

23. Welland A, Daff S. Conformation-dependent hydride transfer in neuronal nitric oxide synthase reductase domain. FEBS J. 2010; 277(18): 38333843.

24. Veklich TO, Kosterin SO, Shynlova OP. Cationic specificity of a $\mathrm{Ca}^{2+}$-accumulating system in smooth muscle cell mitochondria. Ukr Biokhim Zhurn. 2002; 74(1): 42-48. (In Ukrainian).

25. Kone BC, Kuncewicz T, Zhang W, Yu ZY. Protein interactions with nitric oxide synthases: controlling the right time, the right place, and the right amount of nitric oxide. Am J Physiol Renal Physiol. 2003; 285(2): F178-F190.

26. Sasaki T, Naka M, Nakamura F, Tanaka T. Ruthenium red inhibits the binding of calcium to calmodulin required for enzyme activation. J Biol Chem. 1992; 267(30): 21518-21523.

27. Babich LH, Shlykov SH, Naumova NV, Kosterin SO. Use of flow cy tometry to determine $\mathrm{Ca}^{2+}$ content in mitochondria and influence of calmodulin antagonists on it. Ukr Biokhim Zhurn. 2008; 80(4): 51-58. (In Ukrainian).

28. Kojima H, Nakatsubo N, Kikuchi K, Kawahara S, Kirino Y, Nagoshi H, Hirata Y, Nagano T. Detection and imaging of nitric oxide with novel fluorescent indicators: diaminofluoresceins. Anal Chem. 1998; 70(13): 2446-2453.

29. Campbell AK. Intracellular calcium. John Wiley \& Sons, Ltd. 2015.

30. Shlykov SG, Babich LG, Kosterin SA. Suspension of digitonin-treated smooth muscle cells as model of the calcium pump of myometrial endoplasmic reticulum. Biochemistry (Mosc). 1997; 62(12): 1666-1671. (In Russian).

31. Fiskum G. Intracellular levels and distribution of $\mathrm{Ca}^{2+}$ in digitonin-permeabilized cells. Cell Calcium. 1985; 6(1-2): 25-37.

32. Durán WN, Breslin JW, Sánchez FA. The NO cascade, eNOS location, and microvascular permeability. Cardiovasc Res. 2010; 87(2): 254-261.

33. Szydlarska J, Weiss C, Marycz K. The Effect of Methyl- $\beta$-cyclodextrin on apoptosis, proliferative activity, and oxidative stress in adipose-derived mesenchymal stromal cells of horses suffering from metabolic syndrome (EMS). Molecules. 2018; 23(2). pii: E287. 